\title{
Indonesian young consumers' intention to donate using sharia fintech
}

\author{
Maulida Dwi Agustiningsih¹, Ravika Mutiara Savitrah², Putri \\ Catur Ayu Lestari ${ }^{3 *}$ \\ ${ }^{1}$ Faculty of Ushuluddin, Adab and Humaniora, UIN Kiai Haji Achmad Siddiq, \\ Jember, Indonesia \\ 2,3Faculty of Economics and Islamic Business, UIN Kiai Haji Achmad Siddiq, \\ Jember, Indonesia \\ ${ }^{*}$ Corresponding author: putricatural@iain-jember.ac.id
}

\begin{abstract}
Purpose: This research examines the effect of Perceived Ease of Use (PEOU), Perceived Usefulness (PU), religiosity, and company image on intention to use Sharia fintech for donation among Indonesian young consumers.
\end{abstract}

Methodology: This study used a quantitative method with data collection techniques using an online questionnaire. Respondents filled out the questionnaire based on the Likert scale from 1 (strongly disagree) to 4 (strongly agree). The questionnaire was distributed and collected in less than one week, from 26th March 2021 to 29th March 2021. The ideal sample is five times higher than the number of indicators. The number of indicators is 20 , so the ideal sample is 100 or more. This study has successfully collected 206 respondents. However, 13 respondents filled the same scale for all questions, so 193 is chosen as data analysis. The valid data were analyzed through Structural Equation Modeling Partial Least Square (SEM-PLS).

Findings: This research shows the intention to use Sharia fintech to pay donations influenced by perceived usefulness (PU) and religiosity. In contrast, perceived ease of use (PEOU) and image are not positively related to the intention of using Sharia fintech for donation.

Practical Implication: Religiosity and PU positively influence the interest in using Sharia fintech to pay donation. So, it is expected for fintech to comply with Sharia compliance and still comply with regulations from the OJK and DSN related to legality aspects. Furthermore, fintech startups and developers can build a more user-friendly application.

Originality: This research is a replication-based model and is adapted from published research. The originality in this research is in the respondent who young generation. Intention to pay donation using fintech Sharia is the main focus to be researched. This primary focus has not been being researched beforehand.

Keyword: fintech, donation, TAM, image, religiosity

Cite this article:

Agustiningsih, M. D., Savitrah, R. M., \& Lestari, P. C. A. (2021). Indonesian Young Consumers' Intention to Donate Using Sharia Fintech. Asian Journal of Islamic Management, 3 (1), 34-44. https://doi.org/10.1108/AJIM.vol3.iss1.art4

\author{
Article history \\ Received, 20 April 2021 \\ Revised 1, 10 May 2021 \\ Revised 2, 21 May 2021 \\ Accepted, 28 May 2021
}

\section{Introduction}

In Indonesia, it was recorded that 196.71 million people use the internet in their daily lives (Badan Pusat Statistik, 2020). The high number of internet users in Indonesia is due to several factors, such as the increasingly even distribution of fast internet or broadband infrastructure and the policy of working and studying from home during the Covid-19 pandemic. One of the implementations of 
digitalization is financial technology, which is a technology that makes it easy for people to carry out financial transactions such as payments, investments, access to capital, transfers, and online financial plans. Fintech in Indonesia has grown along with the lifestyle of online buyers and sellers. Therefore, financial services on fintech are not only in the context of business but also in social activities.

Fintech disrupts how Muslims donate. Using fintech, donors can make a donation simply by scanning code on a smartphone connected to an e-wallet, banking, or fintech application. These phenomena contrast with the conventional donation. Before using fintech, Muslims donate to the mosque or an orphanage (Niswah et al., 2019). During the COVID-19 pandemic, to prevent the spread of the virus, the government made social distancing policies. On the other hand, donations can help affected people, such as MSME actors and workers who have been laid off and people who need donations.

Internal and external factors influence an individual's decision to donate through a fintech platform. Kurniaputri et al. (2020) stated that intention is one of the internal factors that influence the decision to donate through fintech. Meanwhile, previous research studied that the variables that affect muzakki paying zakat through fintech are socialization factors from zakat institutions, costs, convenience, and security of using applications, as well as the credibility of zakat institutions. A study by Aji et al. (2020) concerned about the charity of Islamic adopted theory of reasoned action (TRA) and social presence theory (SPT). In order to get a more comprehensive prediction result of Islamic donation, using alternative theory or framework is suggested. The well-known model used in some previous research on fintech is Technology Acceptance Model (TAM) (Niswah et al., 2019; Darmansyah et al., 2020; Usman et al., 2020). To be accepted by users, applications such as Sharia fintech should be easier to use than the others (Davis, 1989). The TAM theory proposed by Davis (1989) stated that perceived ease of use (PEOU) and perceived usefulness (PU) had a positive effect on interest in using technology.

Religiosity reflects how deep an individual's knowledge, belief, worship, and religious rules are. Islamic religiosity is a manifestation of the understanding and implementation of worship (vertical and horizontal) in accordance with Islamic principles. Muslims who have a high level of religiosity will also have a social concern reflected in the activities of paying zakat, infaq and shodaqah. Paying zakat is a pillar of Islam that must be fulfilled if it reaches the nishab. In addition, donation activities are an instrument of wealth distribution so that wealth does not revolve around the rich. Therefore, the donation helps the overall welfare of the community.

User's behavior and preferences of donation are affected by religiosity (Wijaya \& Mahardika, 2019; Reitsma \& Grotenhuis, 2006). A study conducted by Usman et al. (2020) found that religiosity positively related to donation intention through fintech. It can be said that the higher a person's religiosity, the greater the level of concern for the surrounding environment by channeling donations. Studied by Aji et al. (2020) examined donation based on an intrinsic religious perspective. Meanwhile, this study tries to focus on the extrinsic religious perspective. Sharia fintech must continue to strive for corporate image to attract consumer interest as a new form of donation transaction. In some sectors, the image of a corporation impacts intention (Özkan et al., 2019). To escalate the intention of using Sharia fintech, building a solid corporate image is necessary.

Several previous studies have discussed factors that influence interest in using fintech in general, both for funding, financing, and donation activities (Darmansyah et al., 2020) and fintech for payments to MSMEs (Luckandi, 2018). However, it is still rare to find research that discusses the phenomenon of using Sharia fintech in the younger generation. At the same time, the potential of the younger generation in using fintech is considerable because of its role as the largest internet user who can easily learn the latest technology. In addition, the millennial generation group is in a productive age who already has an income.

Based on the data and some previous studies, the researchers are interested in examining the factors that influence the interest in using Sharia fintech to distribute donations, especially to 
the younger generation. The younger generation has a dynamic character and tends to be aware of technological developments. Thus, this research contributes both practically and theoretically about Indonesian young consumer's intention to donate using Sharia fintech.

\section{Literature review}

\section{Financial Technology}

Financial technology or fintech is defined as financial services based on technology and is developing rapidly in various parts of the world (Luckandi, 2018). In addition, fintech can also be interpreted as integration between technology and financial features that can affect business models (Niswah et al., 2019). A broader definition states that fintech is an industry consisting of several companies that use digital technology in their financial systems and financial services so that it is more efficient (Hiyanti et al., 2019).

Along with the development of the Sharia business, to date, Sharia fintech is also emerging. The difference between conventional fintech and Sharia fintech is that there are certain limitations to the funds provided by investors or lenders and must be in accordance with the fundamental values of Islamic economics, namely divinity (ilahiyyah), justice (al-'adl), prophethood (al-nubuwwab), governance (al-khalifah), and the results (alma'ad) (Alwi, 2018).

The Financial Stability Board (2019) states that fintech companies have a type of business in the form of a loan provider platform, commonly known as peer-to-peer lending, crowdfunding or charity platforms, and payment platforms. According to Rumondang et al. (2019), fintech is classified as digital payment, account aggregator, personal finance, and financing and investment. Digital payment is a fintech company that provides online payment transaction services so that the process becomes more practical, fast, and inexpensive. Usually, this type of company has a digital wallet feature that facilitates various types of online transactions between consumers and business owners or business operators (B2B). Account aggregator, this type of fintech, will offer services to accommodate all transactions through one platform. Users of this platform are provided with easy transaction verification because the process is fast and short. Consumers who have multiple bank accounts can register their accounts on this platform, so they can use them to check all their banking transactions through this platform only.

Personal finance is a type of fintech that provides a platform to help consumers make good financial reports and provide advice on the use of sound finances. Financing and investment, namely fintech companies that provide peer-to-peer lending services (P2P Lending) and crowdfunding services. Typically, fintech companies in this category can be P2P lending, crowdfunding, or combining these two. Feeder site is a type of fintech that provides services to provide the information needed by potential customers who will use financial products and services. Examples of information provided are interest rates, rupiah exchange rates, credit cards, and insurance premiums.

\section{Technology Acceptance Model (TAM)}

As Dillon and Morris's (1996) explanation, the definition of user acceptance of information technology is the measured willingness of a group of users to use information technology to complete a designed task. The well-known model that was primarily used in some previous research is Technology Acceptance Model (TAM). TAM explains some factors in the model, such as user perceptions, perceived ease of use, attitudes, and intentions in using technology. This model is used to determine which factors that most influence the user to use certain technology.

Davis (1989) defined perceived ease of use (PEOU) as the level of someone's belief that using a particular technology does not require a hard effort. Perceived usefulness (PU) is a person's level of belief that using information technology will improve work performance effectively. Using technology, both variable PEOU and PU are significantly effective on interest. Previous studies by Venkatesh and Davis (2000) discussed that usability is one of the strong reasons as a driving force 
for someone's intention to use technology. Perceived ease of use is determinant of perceived usefulness and influence of user intentions in the model of TAM 2. User's intentions are driven by ease and usability.

Fintech application is an integration of the use of technology and financial systems. Niswah et al. (2019) explained that one of the fintech functions is crowdfunding. En attendant, Sharia principles and Islamic2 values are the main underlines of Sharia Fintech. Perceived ease of use is significantly related to use of technology. To determine consumer intentions in using wearable device, perceived ease of use and perceived usefulness affected to the user's intentions. Based on the study literature and previous study, the hypotheses are:

H1: Perceived ease of use (PEOU) is positively relates to intention of using Sharia fintech in order to pay donation

H2: Perceived usefulness (PU) is positively relates to intention of using Sharia fintech in order to pay donation

H3: Perceived ease of use (PEOU) is positively relates to perceived usefulness (PU) in order to pay donation

\section{Religiosity}

Religiosity comes from the Latin religio, which means binding. Religiosity relates to a person's level of faith, meaning that the higher the level of one's faith, the greater the commitment to carry out God's commands and stay away from His prohibitions. According to Abdullah and Siddique (1988), religiosity is defined as the act of expressing religious teachings through the ritual behavior of maghdah and ghairu maghdah (social activities). Therefore, one's religiosity is not only reflected in vertical worship but also in daily decision-making, including in economic activities (Khan and Qianli, 2017). Previous research has stated that the aspect of religiosity affects a person's attitudes and preferences. Aspects of religiosity affect the choice of using halal products (Divianjella et al., 2020; Aji, 2017; Khibran, 2019), using Islamic financial products (Muslichah \& Sanusi, 2019; Khotimah, 2018), and channeling donations (Usman et al., 2020; Yunus, 2016).

Currently, donation activities can be carried out directly or through social fund management institutions. Social fund management institutions can be reached by murakki either offline (at the office) or online transaction, commonly known as e zakat. Even fintech innovation facilitates users to channel donation, which is known as crowdfunding. Yunus (2016), in his research, states that the religiosity of zakat payments through Baitul Maal Watamwil. Meanwhile, Usman et al. (2020) proved the significant influence of the religiosity aspect on the intention of using technology for donation. Based on previous research, the hypothesis in this study is as follows:

H4: Religiosity is positively relates to intention of using Sharia fintech in order to pay donation

\section{Image}

Company image is a multidimensional construct that is influenced by emotions, symbols, and consumer attitudes (Malik et al., 2012). As a new form of business, fintech must continue to improve its corporate image to attract consumer interest. Company image has a vital role in increasing consumer loyalty, so that special attention from companies is to build a positive image in the eyes of society (Usman et al., 2020). In addition, a company's success is greatly influenced by the image inherent in the company and believed by the public (Özkan et al., 2019).

Company image is closely related to brand image theory which states that company image represents consumer impressions and interests towards these products. Product image generally impacts marketing performance indicators such as buying interest and customer loyalty (Karaosmanoglu et al., 2011). Research on the effect of corporate image on the use of Islamic fintech has not been found primarily in Indonesia. Several studies on the corporate image were only conducted to see the effect on consumer loyalty, namely research from Özkan et al. (2019) and Yilmaz et al. (2018). Meanwhile, Usman et al. (2020) stated that corporate image could not 
moderate the relationship between consumers' attitude in using fintech towards the value of convenience and fintech use. Based on the explanation above, the hypothesis in this study is:

H5: Company image is positively relates to intention of using Sharia fintech in order to pay donation

\section{Methods}

This study used quantitative method with data collection techniques using an online questionnaire. In terms of its goals, this research is an explanatory study that explains a reason for a relationship between different aspects of the research scope (Anshori dan Iswati, 2009). Respondents filled out the questionnaire based on the Likert scale starting from 1 ("strongly disagree") to 4 ("strongly agree").

The questionnaire was distributed and collected in less than one week, from 26th March 2021 to 29th March 2021. The ideal sample is five times higher than the number of indicators. The number of indicators is 20 , so the ideal sample is 100 or more. Two hundred six respondents were collected; however, 13 respondents filled the same scale for all questions. So, the rest of the 193 data is chosen for the data analysis. The valid data were analysed through Structural Equation Modelling Partial Least Square (SEM-PLS).

Table 1. Operational Definitions of Variables

\begin{tabular}{ll}
\hline \multicolumn{1}{c}{ Variable } & \multicolumn{1}{c}{ Operational Definition } \\
\hline Perceived Ease of Use (PEOU) & $\begin{array}{l}\text { A person's belief that using certain technologies does not require } \\
\text { strenuous performance efforts (Davis, 1989) } \\
\text { Someone's belief that the use of information technology will }\end{array}$ \\
Perceived Usefulness (PU) & $\begin{array}{l}\text { improve performance (Davis, 1989) } \\
\text { The value of action religiosity depicting religious teachings reflected } \\
\text { Religiosity }\end{array}$ \\
& in the behavior of maghdah and ghairu maghdah worship rituals (social \\
& activities) (Abdullah and Siddique, 1988) \\
Amage & A multidimensional construct that is influenced by emotions, \\
& symbols, and attitudes of consumers (Özkan, 2017) \\
Intention & A person's tendency to choose to do or not do a job (Usman, 2017) \\
\hline
\end{tabular}

\section{Theoretical Framework}

This study aims to identify the factors that influence donations through Islamic fintech. This study uses a sample of the younger generation because it is considered the generation most adaptable to technological developments. Figure 1 describes the relationship between variables used in this study. Meanwhile, the operational definitions of variables are explained on Table 1.

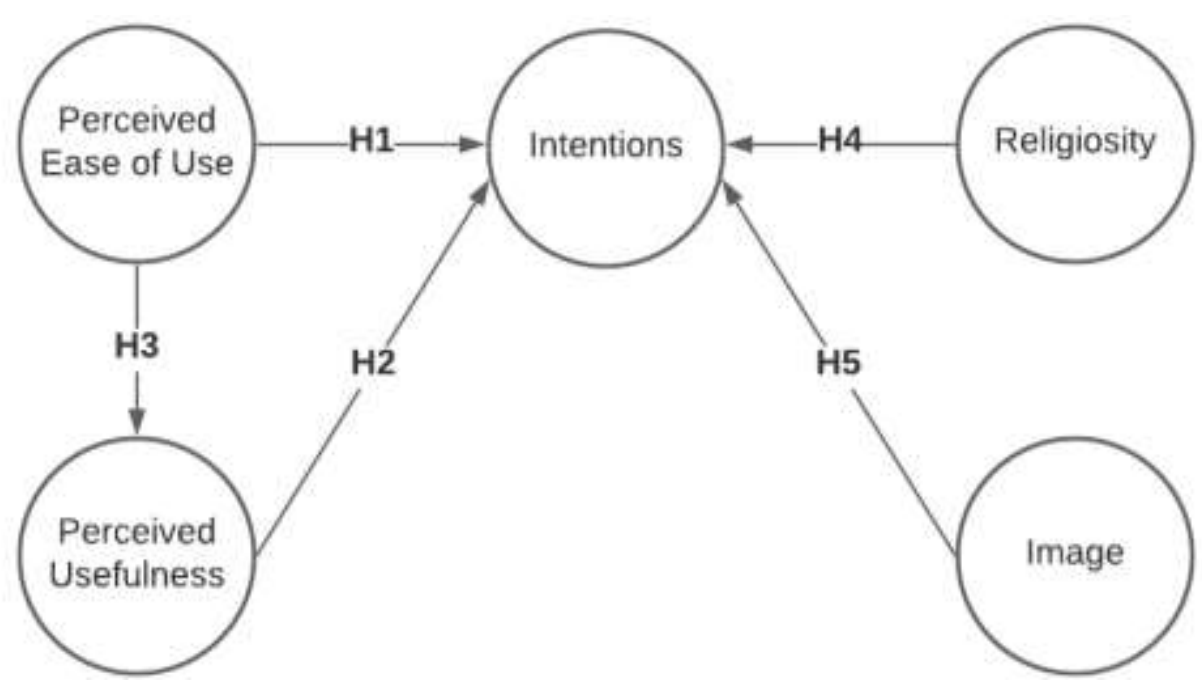

Figure 1. Theoretical Framework 


\section{Results}

\section{Demographic Profile}

The research data were obtained from questionnaires distributed via google form and social media. After the data collection process, as many as 193 respondents were declared valid and then carried out demographic characteristics based on gender and age. Of the total respondents, the productive age generation with the age range 25-34 years dominates with $83 \%$, and the rest is the group in the 18 -24 age range, namely $17 \%$. Based on gender, the number of female respondents $(53 \%)$ is greater than males. Overall, the profile of respondents is displayed on Table 2.

Tabel 2. Demographic Data

\begin{tabular}{lcc}
\hline Category & Number of respondents & Percentage \\
\hline Gender & & \\
Male & 90 & $46,7 \%$ \\
Female & 103 & $53,3 \%$ \\
Age Range & & \\
$18-24$ & 33 & $17,1 \%$ \\
$25-34$ & 160 & $82,9 \%$ \\
\hline
\end{tabular}

\section{Validity and Reliability Test}

Table 3 presents the results of the validity test of each variable in this study. It can be seen that the factor loading value of all instruments in all research models is more than 0.7. It can be concluded that the instruments used are appropriate to measure the intention of the younger generation to make donations using Sharia fintech. In addition, the results of this study are valid and can be generalized to all different objects, situations, and times.

Table 3. Validity Test

\begin{tabular}{lrrrrr}
\hline & Image & Intentions & PEOU & PU & Religiosity \\
\hline I1 & 0,846 & & & & \\
I2 & 0,799 & & & & \\
I3 & 0,831 & & & & \\
IUD1 & & 0,897 & & & \\
IUD2 & & 0,922 & & & \\
IUD3 & 0,931 & & & \\
IUD4 & 0,838 & & & \\
PEOU1 & & & 0,869 & & \\
PEOU2 & & 0,908 & & \\
PEOU3 & & 0,911 & & \\
PEOU4 & & 0,866 & & \\
PU1 & & & 0,779 & \\
PU2 & & & 0,848 & \\
PU3 & & & 0,873 & \\
PU4 & & & 0,749 & \\
RD1 & & & & 0,916 \\
RD3 & & & & \\
\hline
\end{tabular}

Based on the rule by Hair et al. (2014), the average extracted for model evaluation, convergent validity, AVE must be higher than 0.5. Internal consistency reliability, composite reliability must be higher than 0.70 . Cronbach's alpha values are greater than 0.7 . Table 4 shows that the composite reliability and Cronbach's alpha scores are greater than 0.7 , indicating fulfilling the reliability assumption. 
Table 4. Reliability Test

\begin{tabular}{lrrrr}
\hline \multicolumn{1}{c}{ Variables } & $\begin{array}{c}\text { Cronbach's } \\
\text { Alpha }\end{array}$ & rho_A & Composite Reliability & $\begin{array}{c}\text { Average Variance Extracted } \\
\text { (AVE) }\end{array}$ \\
\hline Image & 0,768 & 0,778 & 0,865 & 0,682 \\
Intentions & 0,920 & 0,926 & 0,943 & 0,806 \\
PEOU & 0,911 & 0,915 & 0,937 & 0,789 \\
PU & 0,831 & 0,844 & 0,886 & 0,662 \\
Religiosity & 0,800 & 0,800 & 0,909 & 0,833 \\
\hline
\end{tabular}

\section{Hypothesis Testing}

Hypothesis testing in this study is illustrated in Figure 2. The hypothesis testing result is shown in Table 5, in which each of $\mathrm{H} 2, \mathrm{H} 3$, and $\mathrm{H} 4$ is accepted, while $\mathrm{H} 1$ and $\mathrm{H} 5$ are rejected.

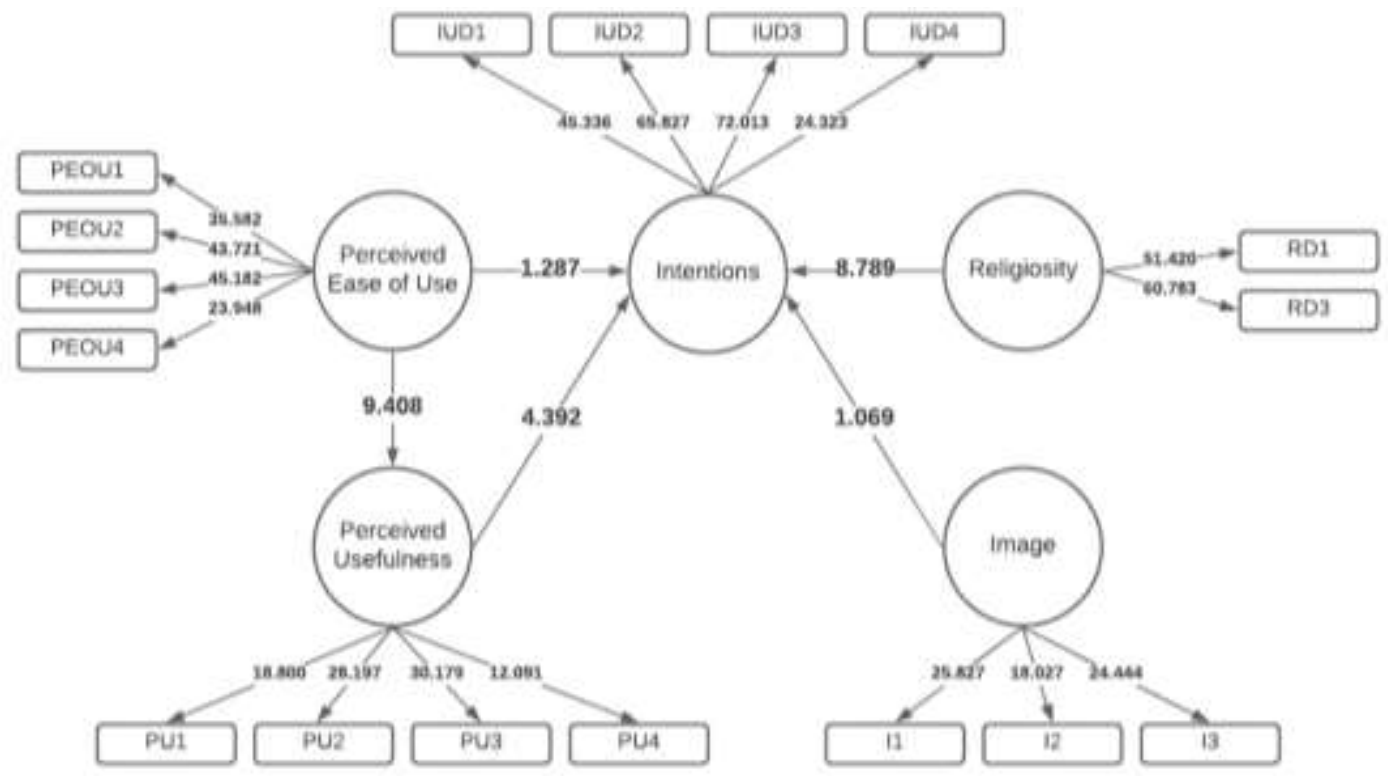

Figure 2. Path Value Diagram

Table 5. Hypotheses Testing Result

\begin{tabular}{llcccc}
\hline Hypothesis & \multicolumn{1}{c}{ Path } & $\begin{array}{c}\text { Original Sample } \\
(\mathbf{O})\end{array}$ & $\begin{array}{c}\text { T Statistics } \\
(\mid \mathbf{O} / \text { STDEV } \mid)\end{array}$ & P Values & Result \\
\hline H1 & PEOU $\rightarrow$ Intentions & $-0,089$ & 1,287 & 0,199 & Rejected \\
H2 & PEOU $\rightarrow$ PU & 0,596 & 9,408 & 0,000 & Accepted \\
H3 & PU $\rightarrow$ Intentions & 0,264 & 4,392 & 0,000 & Accepted \\
H4 & Religious $\rightarrow$ Intentions & 0,608 & 8,789 & 0,000 & Accepted \\
H5 & Image $\rightarrow$ Intentions & 0,067 & 1,069 & 0,285 & Rejected \\
\hline
\end{tabular}

\section{Discussion}

Perceived ease of use (PEOU) positively relates to perceived usefulness (PU) to pay donation on fintech Platform. This result confirmed TAM 2 that perceived ease of use is a determinant of perceived usefulness and influence of user intentions.

Perceived ease of use (PEOU) has no effect on users' intentions to use fintech to pay donations. This result is supported by previous research conducted by Niswah et al. (2019). Most Indonesians feel it easy to pay donations through mosques, social institutions, and social fundraising rather than using fintech. Moreover, not everyone who wants to donate has a fintech 
application on their smartphone. Meanwhile, perceived usefulness (PU) is positively related to the user's intention. One of the factors that influence a user's intention in using fintech is the benefit. The higher the value of benefits felt by users, the higher the level of one's interest in using the system (Niswah et al., 2019). Kim et al.. (2018) showed that perceived usefulness affects users to make transactions on fintech.

Based on the hypothesis test, the religiosity variable has a significant positive effect on the interest in distributing donations (crowdfunding) using the Sharia fintech application. It means that the higher the level of one's faith, the greater the commitment to act under the religious principles because the religiosity component is not only on belief and understanding of religion but also reflected in practice in everyday life (Stark \& Glock, 1969). In Islamic teachings, humans of the highest rank are the ones who provide the most benefits. So that the greater the donation that is distributed, the greater the benefits that are distributed. In addition, from every property owned by a Muslim, there are rights of other people who need it. Therefore, a Muslim who has reached the nishab is obliged to give zakat. The donation distribution activity is an implementation of Islamic teachings as rabmatan lil alamin.

Based on the results of the hypothesis testing, it is proven that company image has a positive influence on the interest in using Sharia fintech in terms of donations. However, it is not significant. Thus, the hypothesis is rejected. This result contradicts the previous study by Özkan et al. (2019), which states that company image positively affects consumer loyalty. This result is also not aligned with research by Usman (2017), which states that the company image is the basis for decision-making by consumers even though consumers do not know for sure the quality of the products produced by the company. The younger generation in using Sharia fintech to donate is only based on a booming platform and prioritizes the transaction easiness, so that company image is no longer a factor that influences the interest in using Sharia fintech to donate.

Company image is an essential factor to pay attention to, especially in the Islamic financial technology industry. It is because Islamic fintech does not have tangible products whose quality can be directly measured and assessed (Özkan et al., 2019). This situation makes Sharia fintech companies really build the best possible company image in the eyes of consumers to win the competition in the market. In addition, company image is the most important asset for fintech because a good image will provide a sustainable competitive advantage.

\section{Conclusion and Recommendations}

Based on the results of statistical tests with PLS, perceived convenience does not influence the interest in using Sharia fintech for donation activities. It is possibly due to the low popularity of Sharia fintech in the eyes of the public so that changes in people's behavior from traditional methods to using technology have not been implemented in daily transactions. Meanwhile, perceived convenience affects the perceived usefulness of Sharia fintech in donation activities. The easier the application is, the higher the younger generation's perception of the useful of Sharia fintech for donations. Perceived usefulness affects the interest in using Sharia fintech in donation activities. It is because the younger generation likes things that are simple and have real benefits.

Furthermore, religiosity influences the interest in using Sharia fintech for paying donations. So, it is expected for fintech to comply with Sharia compliance and still comply with regulations from the OJK and DSN related to legality aspects. Image has no influence on the interest in using Sharia fintech in donation activities because the younger generation in using Sharia fintech to donate is only based on a booming platform and also prioritizes ease of transactions so that the company's image is no longer a factor that influences the interest in using Sharia fintech to donate. However, this study has limitations on the research sample that is only distributed in Java. The next research is expected to have a wider coverage area to obtain more representative research results. In addition, it is suggested to explore other variables that are thought to have an effect on the interest in using Sharia fintech. 


\section{References}

Abdullah \& Siddique. (1988). Tradisi dan kebangkitan Islam di Asia Tenggara. Jakarta: LP3ES.

Aji, H.M. (2017). Examining the moderating role of high-versus-low scepticism toward Halal labels: Findings from Indonesia. International Journal of Islamic Marketing and Branding, 2(4), 278-303. https://doi.org/10.1504/IJIMB.2017.088999

Aji, H. M., Albari, A., Muthohar, M., Sumadi, S., Sigit, M., Muslichah, I., \& Hidayat, A. (2020). Investigating the determinants of online infaq intention during the COVID-19 pandemic: An insight from Indonesia. Journal of Islamic Accounting and Business Research, 12(1), 1-20. https://doi.org/10.1108/JIABR-05-2020-0136

Alwi, A. B. (2018). Pembiayaan berbasis teknologi informasi (fintech) yang berdasarkan syariah. Jurnal Al- Qonun, 21(2). http://dx.doi.org/10.15642/alqanun.2018.21.2.255-271

Badan Pusat Statistik. (2020). Statistik Indonesia 2020. Jakarta: Badan Pusat Statistik.

Darmansyah, Fianto, B. A., Hendratmi, A., \& Aziz, P. F. (2020). Factors determining behavioral intentions to use Islamic financial technology: Three competing models. Journal of Islamic Marketing. 12(4). 794-812. https://doi.org/10.1108/JIMA-12-2019-0252

Davis, F. D. (1989). Perceived usefulness, perceived ease of use, and user acceptance of information technology. MIS Quarterly: Management Information Systems, 13(3), 319-339. https://doi.org/10.2307/249008

Divianjella, M., Muslichah, I., \& Ariff, Z.H.A. (2020). Do religiosity and knowledge affect the attitude and intention to use halal cosmetic products? Evidence from Indonesia. Asian Journal of Islamic Management. 2(2). 71-81. https://doi.org/10.1108/AJIM.vol2.iss2.art1

Dillon, A., \& Morris, M. G. (1996). User acceptance of information technology: Theories and models. Annual Review of Information Science and Technology (ARIST), 31, 3-32.

Financial Stability Board. (2019). Fintech and market structure in financial services: Market developments and potential financial stability implications. Retrieved from https://www.fsb.org/wp-content/uploads/P140219.pdf

Hair, J.F, Sarstedt, M., Hopkins, L., \& G. Kuppelwieser, V. (2014). Partial least squares structural equation modeling (PLS-SEM): An emerging tool in business research. European Business Review, 26(2), 106-121. https://doi.org/10.1108/EBR-10-2013-0128

Hiyanti, H., Nugroho, L., Sukmadilaga, C., \& Fitrijanti, T. (2019). Peluang dan Tantangan Fintech (Financial Technology) Syariah di Indonesia. Jurnal Ilmiah Ekonomi Islam, 5(3), 326-333. http://dx.doi.org/10.29040/jiei.v5i3.578

Karaosmanoglu, E., Bas, A.B.E. and Zhang, J. (2011), The role of other customer effect in corporate marketing: its impact on corporate image and consumer-company identification. European Journal of Marketing, 45(10), 1416-1445, https://doi.org/10.1108/03090561111151835

Khibran, M. (2019). An investigation toward purchase intention of Halal beef from traditional market: A TPB perspective. Asian Journal of Islamic Management, 1(1), 1-12. http://dx.doi.org/10.20885/ajim.vol1.iss1.art1

Khan, S. A., \& Qianli, D. (2017). Does national scale economic and environmental indicators spur logistics performance? Evidence from UK. Environmental Science and Pollution Research. 24. 26692-26705. https://doi.org/10.1007/s11356-017-0222-9

Khotimah, N. (2018). Pengaruh religiusitas, kepercayaan, citra perusahaan, dan sistem bagi hasil terhadap minat nasabah menabung dan loyalitas di Bank Syariah Mandiri (Studi kasus pada 
nasabah Bank Syariah Mandiri Gresik). JMM17 Jurnal Ilmu Ekonomi \& Manajemen, 5(1), 37-48. https://doi.org/10.30996/jmm17.v5i01.1712

Kurniaputri, M. R., Dwihapsari, R., Huda, N., \& Rini, N. (2020). Intensi Perilaku Dan Religiusitas Generasi Millenials Terhadap Keputusan Pembayaran ZIS Melalui Platform Digital. EQien: Jurnal Ekonomi dan Bisnis, 7(2). 15-22. https://doi.org/10.34308/eqien.v7i2.134

Kim, T., \& Chiu, W. (2018). Consumer acceptance of sports wearable technology: the role of technology readiness. International Journal of Sports Marketing and Sponsorship, 20(1), 109-126. https://doi.org/10.1108/IJSMS-06-2017-0050

Luckandi, D. (2018). Analisis Transaksi Pembayaran Menggunakan Fintech Pada UMKM di Indonesia : Pendekatan Adaptive Structuration Theory. DSpace, 4, 1-98. Retrieved from https://dspace.uii.ac.id/handle/123456789/9681

Malik, M. E., Naeem, B., \& Munawar, M. (2012). Brand Image: Past, Present and Future Muhammad. Journal of Basic and Applied Scientific Research, 2(12), 13069-13075.

Muslichah, I., \& Sanusi, S. (2019). The effect of religiosity and financial literacy on intention to use Islamic banking products. Asian Journal of Islamic Management (AJIM), 1(2), 85-92. https://doi.org/10.20885/ajim.vol1.iss2.art2

Niswah, F. M., Mutmainah, L., \& Legowati, D. A. (2019). Muslim Millennial'S Intention of Donating for Charity Using Fintech Platform. Journal of Islamic Monetary Economics and Finance, 5(3), 623-644. https://doi.org/10.21098/jimf.v5i3.1080

Özkan, P., Süer, S., Keser, İ. K., \& Kocakoç, İ. D. (2019). The effect of service quality and customer satisfaction on customer loyalty: The mediation of perceived value of services, corporate image, and corporate reputation. International Journal of Bank Marketing, 38(2), 384-405. https://doi.org/10.1108/IJBM-03-2019-0096

Reitsma, J., Scheepers, P., \& Grotenhuis, M. Te. (2006). Dimensions of individual religiosity and charity: Cross-national effect differences in European countries? Review of Religious Research, 47(4), 347-362.

Rohmah, I. L., Ibdalsyah, I., \& Kosim, A. M. (2020). Pengaruh Persepsi Kemudahan Berdonasi, Dan Efektifitas Penyaluran Menggunakan Fintech Crowdfunding Terhadap Minat Membayar Zakat, Infaq, Shadaqoh. Jurnal Ekonomi Islam, 13(1), 42-51. http://dx.doi.org/10.32832/kasaba.v13i1.3397

Rumondang, A., Sudirman, A., Effendy, F., Simarmata, J., \& Agustin, T. (2019). Fintech: Inovasi Sistem Kenangan di Era Digital. Yayasan Kita Menulis.

Stark, R., \& Glock, C. Y. (1969). American piety: The nature of religious commitment. American Journal of Sociology, 74(6). https://doi.org/10.1086/224728

Usman, H., Mulia, D., Chairy, C., \& Widowati, N. (2020). Integrating trust, religiosity and image into technology acceptance model: The case of the Islamic philanthropy in Indonesia. Journal of Islamic Marketing. https:/ /doi.org/10.1108/JIMA-01-2020-0020

Usman, H. (2016). Islamic religiosity scale, and its applied on the relationship between religiosity and selection of Islamic bank. Journal of Distribution Science, 14(2), 23-32. https://doi.org/10.15722/JDS.14.2.201602.23

Venkatesh, V. \& Davis, F. D. (2000). A Theoretical Extension of the Technology Acceptance Model: Four Longitudinal Field Studies. Management Science, 46(2), 186-204. https://www.jstor.org/stable/pdf/2634758.pdf

Wijaya, T. \& Mahardika, T.P. (2019), The effects of consumer knowledge and religiosity on halal cosmetics buying intention with consumer's attitude as the mediation variable, Sumerianz 
Journal of Business Management and Marketing, 2(11), 130-135.

Yunus, M. (2016). Analisis pengaruh kepercayaan, religiusitas dan kontribusi terhadap minat pedagang mengeluarkan zakat di baitul mal (Studi kasus pada pedagang pasar Lhokseumawe). At-Tawassuth, 1(1), 95-124. http://dx.doi.org/10.30821/ajei.v1i1.365 